Vol. 9 (2000): 201-215.

\title{
Undersowing Italian ryegrass diminishes nitrogen leaching from spring barley
}

\author{
Riitta Lemola, Eila Turtola \\ Agricultural Research Centre of Finland, Plant Production Research, FIN-31600 Jokioinen, Finland, \\ e-mail: riitta.lemola@mtt.fi \\ Christian Eriksson \\ Agricultural Research Centre of Finland, Data and Information Services, FIN-31600 Jokioinen, Finland
}

\begin{abstract}
Nitrogen $(\mathrm{N})$ leaching from spring barley with and without undersown Italian ryegrass was studied in Jokioinen, south-western Finland during five years (summer 1993-spring 1998) in $1.7 \mathrm{~m}$ deep lysimeters $(\varnothing 0.9 \mathrm{~m})$ filled to $1.1 \mathrm{~m}$ with clay, silt, sand and peat soil. Tillage was performed in midOctober or in May, before sowing of the barley and ryegrass for the next season. In the second, third and fourth years of the experiment, total $\mathrm{N}$ leaching from barley without undersown ryegrass was 15 , $7.9,32$ and $38 \mathrm{~kg} \mathrm{ha}^{-1} \mathrm{y}^{-1}$ in clay, silt, sand and peat soil, respectively. Undersowing reduced $\mathrm{N}$ leaching by $52,31,68$ and $27 \%$. The reduction in $\mathrm{N}$ leaching from clay and sand when barley was undersown with ryegrass was nearly the same as the increased total uptake of $\mathrm{N}$ (barley + ryegrass). In sand soil, ryegrass was able to diminish the $\mathrm{NO}_{3}-\mathrm{N}$ concentration of the drainage water well below the limit for acceptable drinking water. Spring tillage reduced $\mathrm{N}$ leaching only on peat soil $(16 \%)$. Slight competition between the main and the undersown crop was indicated by lower $\mathrm{N}$ contents of the barley yield.
\end{abstract}

Key words: barley, lysimeter, nitrate nitrogen, primary tillage, soil type, total nitrogen, yield

\section{Introduction}

Nitrogen $(\mathrm{N})$ leaching from cultivated soil tends to be greatest in unfrozen and unvegetated periods, when crop uptake of $\mathrm{N}$ does not deplete the soil of nitrate $\mathrm{N}\left(\mathrm{NO}_{3}-\mathrm{N}\right)$ or ammonium $\mathrm{N}\left(\mathrm{NH}_{4}-\right.$ $\mathrm{N})$ mineralized from soil organic $\mathrm{N}$ and crop residues or derived from fertilizers (Nielsen and
Jensen 1985, Martinez and Guiraud 1990). The unvegetated period is especially long with spring cereals, which occupy about $60 \%$ of the cultivated area in Finland (Yearbook of Farm Statistics 1999). In southern Finland, the leaching risk is highest during three months in autumn after harvest (from mid-August to mid-November) and one month in spring (April), when the runoff volumes are higher due to lower evapotranspiration (au- 
Lemola, $R$. et al. Undersowing Italian ryegrass diminishes $N$ leaching from spring barley

tumn) and excessive water flow through the soil during the final phase of snowmelt (spring).

To protect Finnish lakes and coastal waters from eutrophication, and groundwater from high $\mathrm{N}$ concentrations, the $\mathrm{N}$ load from agriculture should be reduced by $50 \%$ by the year 2005 relative to the load in 1990-93 (Ministry of Environment 1998). One way to decrease N leaching in spring cereal cultivation might be planting of catch crops, which keep the soil covered by growing plants and take up (catch) $\mathrm{N}$ during autumn. In the Nordic countries, where the growing period after cereal harvest is especially short, the low temperature in autumn limits the growth and uptake of residual $\mathrm{N}$ if the catch crop is sown after cereal harvest. In contrast, establishing the catch crop in spring by undersowing enables immediate uptake of residual $\mathrm{N}$ by the catch crop after harvest of the main crop (Breland 1996b, Karlsson-Strese et al. 1998).

A fast growing grass like ryegrass undersown as a catch crop, has a high potential to reduce $\mathrm{N}$ leaching (Hansen and Djurhuus 1997, Aronsson and Torstensson 1998) or the risk of leaching, as deduced from decreased soil mineral $\mathrm{N}$ content in late autumn (Andersen and Olsen 1993, Beck-Friis et al. 1994, Wallgren and Lindén 1994, Känkänen 1995, Breland 1996b, Lyngstad and Børresen 1996). However, the competion between the main crop and the catch crop for light, water and nutrients during the growing season may retard the growth of the main crop.

Tillage initiates mineralization processes in the soil, leading to the release of inorganic $\mathrm{N}$, mainly in the form of $\mathrm{NO}_{3}-\mathrm{N}$. Early autumn ploughing has been reported to increase mineral $\mathrm{N}$ content of soil in late autumn (Lindén and Wallgren 1993, Wallgren and Lindén 1994, Känkänen and Nykänen-Kurki 1997, Stenberg et al. 1999) and thereby to increase the risk of leaching during the following winter and spring. Hence, a second advantage of undersowing the catch crop instead of establishing it after harvest is that no extra tillage is needed after harvest of the main crop, and the stimulation of $\mathrm{N}$ mineralization by early autumn tillage is avoided.
In Finland, the use of catch crops to prevent $\mathrm{N}$ leaching has so far been restricted to a few horticultural crops in a limited area. To date, there have been no direct measurements of the effectiveness of catch crops in reducing $\mathrm{N}$ leaching in Finland, where both $\mathrm{N}$ leaching and the potential of the catch crop to take up residual $\mathrm{N}$ are lower than, for example, in southern Sweden or Denmark. Lack of knowledge about the effectiveness of catch crops in diminishing $\mathrm{N}$ losses to watercourses has probably been one of the reasons for the only minor adoption of the practice.

The aim of the lysimeter experiment reported here was to estimate the potential of undersown Italian ryegrass to reduce $\mathrm{N}$ leaching from different soils (clay, silt, sand and peat) in southern Finland. Italian ryegrass was chosen as the catch crop because of earlier findings of its efficiency in reducing mineral $\mathrm{N}$ content of the soil in autumn (Breland 1996b, Lyngstad and Børresen 1996). The effect of postponing tillage until spring was also investigated.

\section{Material and methods}

\section{The experimental set-up}

The experiment was carried out in a lysimeter field established in 1981 at the Agricultural Research Centre at Jokioinen, south-western Finland (Jaakkola 1984). The annual precipitation in the area is $600-700 \mathrm{~mm}$, and the soil is frozen and snow-covered from November to April (Table 1). The lysimeter field is surrounded by a steel net to a height of $2 \mathrm{~m}$, which results in a slightly thicker snow accumulation on the lysimeters. This, together with heat flow from the underlying water sampling corridor $\left(7-12^{\circ} \mathrm{C}\right)$, caused the annual frozen period to be about 20 days shorter in the lysimeters than in the field. There were two blocks of 40 lysimeters ( 80 lysimeters in total), which had been packed in 1981, layer by layer (0-20, 20-40, 40-80 and 
Vol. 9 (2000): 201-215.

Table 1. Total precipitation (of which irrigation in parenthesis), maximum amount of water in snow in spring, dates of snow cover and frost and maximum depth of frost during the experiment.

\begin{tabular}{lllllrr}
\hline Year & $\begin{array}{l}\text { Total } \\
\text { precipitation } * \\
\text { mm }\end{array}$ & $\begin{array}{l}\text { Max. water in } \\
\text { snow } * * \\
\text { mm }\end{array}$ & $\begin{array}{l}\text { Snow } \\
\text { cover } * * \\
\text { date }\end{array}$ & $\begin{array}{l}\text { Frost } * * \\
\text { date }\end{array}$ & $\begin{array}{l}\text { Max.frost } \\
\text { depth } * * \\
\text { cm }\end{array}$ & $\begin{array}{l}\text { Frost } * * * \\
\text { date }\end{array}$ \\
\hline $1993 / 94$ & $597(26)$ & 84 & $14.11-10.4$ & $22.10-28.4$ & 57 & $7.11-16.4$ \\
$1994 / 95$ & $655(48)$ & 73 & $18.12-15.4$ & $4.11-18.4$ & 28 & $14.11-18.4$ \\
$1995 / 96$ & $653(41)$ & 113 & $16.11-18.4$ & $1.11-22.4$ & 48 & $5.12-24.4$ \\
$1996 / 97$ & $714(44)$ & 80 & $12.12-1.4$ & $14.12-2.5$ & 30 & $16.12-24.4$ \\
$1997 / 98$ & $731(53)$ & 45 & $24.11-30.3$ & $23.10-30.4$ & 45 & $13.12-20.4$ \\
$1980-1999$ & 644 & 97 & $20.11-10.4$ & $15.11-21.4$ & 39 & \\
\hline
\end{tabular}

* Values for precipitation measured at Jokioinen meteorological station, $1 \mathrm{~km}$ away from the lysimeters, values for irrigation measured in the lysimeters.

** Measured at Jokioinen meteorological station.

*** Measured in clay lysimeters.

$80-115 \mathrm{~cm})$ to their original bulk density. Below $115 \mathrm{~cm}$ there was a $50 \mathrm{~cm}$ layer of sand. The four soils (clay, silt, sand and Carex peat), described in Table 2, had been randomized to the sets of 10 lysimeters within each block separately.

Table 2. Particle size distribution, $\mathrm{pH}$ and organic $\mathrm{C}$ in experimental soils.

\begin{tabular}{|c|c|c|c|c|c|}
\hline & \multirow[t]{2}{*}{ Depth, cm } & \multicolumn{4}{|c|}{ Soil type } \\
\hline & & Clay & Silt & Sand & Peat \\
\hline Org. C, \% & $0-20$ & 3.6 & 2.7 & 3.1 & 14.4 \\
\hline \multirow[t]{4}{*}{$\mathrm{pH}\left(\mathrm{H}_{2} \mathrm{O}\right)$} & $0-20$ & 5.8 & 6.0 & 5.9 & 5.6 \\
\hline & $20-40$ & 5.8 & 6.5 & 6.0 & 4.7 \\
\hline & $40-80$ & 6.6 & 7.0 & 6.2 & 4.8 \\
\hline & $80-115$ & 7.0 & 7.0 & 6.3 & 5.2 \\
\hline \multicolumn{6}{|c|}{ Particle size distribution (\%) } \\
\hline \multirow[t]{4}{*}{$<0.002 \mathrm{~mm}$} & $0-20$ & 46 & 17 & 13 & 62 \\
\hline & $20-40$ & 58 & 17 & 4 & - \\
\hline & $40-80$ & 54 & 24 & 6 & - \\
\hline & $80-115$ & 54 & 16 & 9 & - \\
\hline \multirow[t]{4}{*}{$0.002-0.02 \mathrm{~mm}$} & $0-20$ & 15 & 62 & 8 & 8 \\
\hline & $20-40$ & 13 & 66 & 3 & - \\
\hline & $40-80$ & 14 & 64 & 3 & - \\
\hline & $80-115$ & 18 & 51 & 4 & - \\
\hline \multirow[t]{4}{*}{$0.02-0.06 \mathrm{~mm}$} & $0-20$ & 17 & 14 & 16 & 3 \\
\hline & $20-40$ & 16 & 13 & 11 & - \\
\hline & $40-80$ & 22 & 10 & 12 & - \\
\hline & 80-115 & 20 & 30 & 16 & - \\
\hline \multirow{4}{*}{$0.06-0.2 \mathrm{~mm}$} & $0-20$ & 10 & 3 & 42 & 11 \\
\hline & $20-40$ & 9 & 2 & 65 & - \\
\hline & $40-80$ & 9 & 1 & 69 & - \\
\hline & $80-115$ & 7 & 3 & 67 & - \\
\hline
\end{tabular}




\section{Lemola, $R$. et al. Undersowing Italian ryegrass diminishes $N$ leaching from spring barley}

The main variables in the experiment were the use of undersown ryegrass as a catch crop and the time of tillage, as follows:

Treatment

No Undersowing, Undersowing,

$\begin{array}{lll} & \mathrm{U}_{0} & \mathrm{U}_{1} \\ \text { Autumn tillage, } \mathrm{T}_{1} & \mathrm{U}_{0} \mathrm{~T}_{1} & \mathrm{U}_{1} \mathrm{~T}_{1} \\ \text { Spring tillage, } \mathrm{T}_{2} & \mathrm{U}_{0} \mathrm{~T}_{2} & \mathrm{U}_{1} \mathrm{~T}_{2}\end{array}$

The four undersowing-tillage combinations were completely randomized to 10 lysimeters within each soil separately, so that there were 2 or 3 lysimeters within each block assigned to each treatment combination.

The experiment lasted for five years (summer 1993-spring 1998) with the fifth year (summer 1997-spring 1998) being an after-effect year. Italian ryegrass (Lolium multiflorum Lam. cv. Turgo) was undersown each year in spring barley (Hordeum vulgare L. cv. Pohto) during the four years 1993-1996. Primary tillage was performed manually with a spade to a depth of $20 \mathrm{~cm}$, either in the middle of October $\left(\mathrm{T}_{1}\right)$ or in May just before seed bed preparation and sowing of the next crop $\left(\mathrm{T}_{2}\right)$. The depths of seed bed preparation, fertilizer placement and barley sowing were 10, 7 and $5 \mathrm{~cm}$, respectively. Seeds of the ryegrass were broadcast and covered with 1 $\mathrm{cm}$ of soil. The distance between the circular rows of the fertilizer and seeds was the same as in standard farming practice in Finland with fertilizer placement $(6-7 \mathrm{~cm})$. Soil surrounding the lysimeters was fertilized and sown in the same way as in the lysimeters, but without undersowing of ryegrass.

The amount of fertilizer N, P and $\mathrm{K}$ was 90 , 25 and $50 \mathrm{~kg} \mathrm{ha}^{-1} \mathrm{y}^{-1}$ for the mineral soils and 45 , 16 and $37 \mathrm{~kg} \mathrm{ha}^{-1} \mathrm{y}^{-1}$ for the peat soil. Amount of seeds for barley was 450 germinating seeds $\mathrm{m}^{-2}$ and for undersown ryegrass $10 \mathrm{~kg} \mathrm{ha}^{-1}$. In 1997 the lysimeters were sown with a mixture of meadow fescue (Festuca pratensis Huds.) and timothy (Phleum pratense L.) (26 kg ha-1), without fertilization.

Grain and straw of barley, harvested between 15 August and 11 September, were weighed, and straw was returned to the lysimeters after small samples were taken for $\mathrm{N}$ analysis. Ryegrass yield in the treatment with autumn tillage $\left(\mathrm{U}_{1} \mathrm{~T}_{1}\right)$ was determined in the middle of October and the hay material was returned to the lysimeters except for small samples taken for $\mathrm{N}$ analysis. Unfertilized hay was cut in autumn, but the yield was not measured.

All water that percolated through the lysimeters as drainage was collected and weighed in plastic containers. The annual number of water samplings was $8-13$, each sampling representing approximately $24-31 \mathrm{~mm}$ of drainage. Samples for water analysis were collected from the plastic containers into polythene bottles and stored in darkness at $+4^{\circ} \mathrm{C}$ before the analysis for total solids (TS), total $\mathrm{N}$ (Tot-N), nitrate $\mathrm{N}$ $\left(\mathrm{NO}_{3}-\mathrm{N}\right)$ and ammonium $\mathrm{N}\left(\mathrm{NH}_{4}-\mathrm{N}\right)$.

TS and Tot- $\mathrm{N}$ were determined in unfiltered samples and $\mathrm{NO}_{3}-\mathrm{N}$ and $\mathrm{NH}_{4}-\mathrm{N}$ in filtered samples (Nuclepore 111106-PC, pore size $0.2 \mu \mathrm{m}$ ). TS was determined as evaporated residue after drying at $105^{\circ} \mathrm{C}$. For the determination of Tot$\mathrm{N}$, inorganic and organic compounds were oxidized to nitrate in alkaline solution under pressure $\left(200 \mathrm{kPa}, 120^{\circ} \mathrm{C}, 0.5 \mathrm{~h}\right)$. The concentration of $\mathrm{NO}_{3}-\mathrm{N}$ was determined colorimetrically $(520 \mathrm{~nm})$ by reducing the nitrate to nitrite with hydrazine sulfate and adding sulfanilamide and N-(1-naphthyl)-ethylenediamine dihydrochloride as reagents. $\mathrm{NH}_{4}-\mathrm{N}$ was analysed colorimetrically $(660$ $\mathrm{nm}$ ) in a slightly alkaline solution with the use of hypochlorite, salicylate and sodium nitroprusside as reagents. The colorimetrical measurements were carried out with a Lachat Quick Chem autoanalyser.

The leaching losses were first calculated on a yearly basis for the five years starting from spring sowing: 1993/94 (8 May1993-6 May1994), 1994/95 (7 May1994-8 May1995), 1995/96 (9 May1995-13 May1996), 1996/97 (14 May1996-13 May 1997) and 1997/98 (14 May1997-27 May1998). The losses are presented below for three periods: (I) the first year (1993/94), (II) the three following years (primary experimental years: 1994/95, 1995/96, 1996/97) and (III) the after-effect year (1997/98) when all lysimeters were under hay. The first year was 
Vol. 9 (2000): 201-215.

studied separately because previous studies had shown that treatments have a delayed effect on the quality of the percolating water. Grain and straw yields were determined on a yearly basis from 1993 to 1996. Within each of the two blocks, the data were reduced by calculating means of the values (leaching losses, yield) of the 2-3 lysimeters.

\section{Statistical analyses}

The experimental design was a split-plot design, where the whole-plot treatments (soils) were in a randomized complete block design with two blocks, and the split-plot treatments (undersowing and tillage time combinations) were randomized to the subplots (lysimeters) within each whole plot separately. Furthermore, after reduction of the data as explained above, repeated measurements were made for each subplot from three or four different periods. Statistical analyses of the data were based on the following mixed model for a split-split-plot design:

$$
\begin{aligned}
Y_{i j k l m}= & \mu+b_{i}+S_{j}+e^{(1)}+T_{k}+U_{l}+T U_{k l}+S T_{j k} \\
& +S U_{j l}+S T U_{j k l}+e_{i j k l}^{(2)}+P_{m}+e_{i m}^{(3)}+S P_{j m} \\
& +e_{i j m}(4)+T P_{k m}+U P_{l m}+T U P_{k l m}+S T P_{j k m} \\
& +S U P_{j l m}+S T U P_{j k l m}+e_{i j k l m}{ }^{(5)}
\end{aligned}
$$

where $Y_{i j k l m}$ is the response for the block i, soil $\mathrm{j}$, tillage time $\mathrm{k}$, use of undersowing $\mathrm{l}$ and period $\mathrm{m} ; \mu$ is the overall mean; $\mathrm{b}$ is the random block effect; S, T, U and P are the fixed effects of soil, tillage time, use of undersowing and period; TU, ST, SU, SP, TP and UP are the twofactor interactions of the fixed effects, STU, TUP, STP and SUP are the three-factor interactions and STUP is the four-factor interaction of the fixed effects; and $e^{(1)}, \ldots, e^{(5)}$ are the random error terms. All random variables were assumed to be independent and normally distributed with zero means and constant variances. The models were fitted by using the residual maximum likelihood (REML) estimation method. The degrees of freedom were approximated by a Satterthwaite procedure (Verbeke and Molenberghs 1997). Accordances of the data with the distributional assumptions of the models were checked by graphic plots. The residuals were checked for normality using a box plot. Furthermore, the residuals were plotted against the fitted values. Such a plot should have the appearance of a random scatter of points if the assumptions of the model are adequate (Yandell 1997). Planned comparisons between means were made by twosided t-type tests. The MIXED procedure (Littell et al. 1996) and UNIVARIATE and PLOT procedures (SAS Institute Inc. 1990) of the SAS/ STAT software were used in the analyses.

While the yield and $\mathrm{N}$ content of the yield were distributed normally, the response variables Tot-N, $\mathrm{NO}_{3}-\mathrm{N}, \mathrm{NH}_{4}-\mathrm{N}$ and TS were distributed non-normally. We therefore used a squareroot transformation for Tot- $\mathrm{N}$ and $\mathrm{NO}_{3}-\mathrm{N}$ and a logarithmic transformation for $\mathrm{NH}_{4}-\mathrm{N}$ and TS.

\section{Results}

\section{Leaching of $\mathrm{N}$}

The treatments did not have any effect on drainage volume, which was $20 \%$ lower in sand soil than in clay and peat soils, and very low in silt soil, especially in the first three years of the experiment. Evaporation was clearly greater from silt soil than from the other soils, so that the water discharge and, consequently, the leaching of $\mathrm{NO}_{3}-\mathrm{N}$ were reduced (Table 3 ). The higher drainage volumes in the final two years were due to higher precipitation (Table 1).

Undersowing reduced the concentration of $\mathrm{NO}_{3}-\mathrm{N}$ in drainage water mainly from the second year onwards, after about 220, 275 and 320 $\mathrm{mm}$ of cumulative drainage from clay, sand and peat soil, respectively. Without undersowing, the average $\mathrm{NO}_{3}-\mathrm{N}$ concentrations in the primary experimental years, weighted by the drainage volume, were 4.5, 5.2, 12 and $12 \mathrm{mg} \mathrm{l}^{-1}$ in clay, silt, sand and peat soil, respectively. Undersowing reduced the concentrations by $54,5.5,69$ and $31 \%$. 
Lemola, $R$. et al. Undersowing Italian ryegrass diminishes $N$ leaching from spring barley

Table 3. Leaching of nitrate $\mathrm{N}\left(\mathrm{NO}_{3}-\mathrm{N}\right)$ and total $\mathrm{N}($ Tot-N), loss of total solids (TS) and drainage from different soils during the first year, second to fourth years (primary experimental years) and fifth year (after-effect year). Treatments: $\mathrm{U}_{0} \mathrm{~T}_{1}=$ no undersowing, autumn tillage; $\mathrm{U}_{1} \mathrm{~T}_{1}=$ undersowing Italian ryegrass, autumn tillage; $\mathrm{U}_{0} \mathrm{~T}_{2}=$ no undersowing, spring tillage; $\mathrm{U}_{1} \mathrm{~T}_{2}=$ undersowing Italian ryegrass, spring tillage.

\begin{tabular}{|c|c|c|c|c|c|}
\hline Soil & Treatment & $\begin{array}{l}\mathrm{NO}_{3}-\mathrm{N}^{*} \\
\mathrm{~kg} \mathrm{ha}^{-1} \mathrm{y}^{-1}\end{array}$ & $\begin{array}{c}\text { Tot-N* } \\
\text { kg ha }^{-1} \mathrm{y}^{-1}\end{array}$ & $\begin{array}{c}\mathrm{TS}^{*} \\
\mathrm{~kg} \mathrm{ha}^{-1} \mathrm{y}^{-1}\end{array}$ & $\begin{array}{c}\text { Drainage } \\
\mathrm{mm}\end{array}$ \\
\hline \multicolumn{6}{|c|}{ First year 1993/94 } \\
\hline \multirow[t]{4}{*}{ Clay } & $\mathrm{U}_{0} \mathrm{~T}_{1}$ & 1.2 & 1.6 & 188 & 217 \\
\hline & $\mathrm{U}_{1}^{\mathrm{T}} \mathrm{T}_{1}$ & 0.5 & 0.7 & 193 & 205 \\
\hline & $\mathrm{U}_{0}^{1} \mathrm{~T}_{2}$ & 1.8 & 2.3 & 197 & 237 \\
\hline & $\mathrm{U}_{1}^{0} \mathrm{~T}_{2}^{2}$ & 0.5 & 0.8 & 217 & 215 \\
\hline \multirow[t]{4}{*}{ Silt } & $\mathrm{U}_{0}^{1} \mathrm{~T}_{1}^{2}$ & 5.3 & 5.6 & 115 & 69 \\
\hline & $\mathrm{U}_{1}^{0} \mathrm{~T}_{1}$ & 1.5 & 1.7 & 28 & 21 \\
\hline & $\mathrm{U}_{0}^{1} \mathrm{~T}_{2}$ & 2.7 & 3.1 & 70 & 57 \\
\hline & $\mathrm{U}_{1}^{0} \mathrm{~T}_{2}^{2}$ & 1.9 & 2.0 & 37 & 24 \\
\hline \multirow[t]{4}{*}{ Sand } & $\mathrm{U}_{0}^{1} \mathrm{~T}_{1}^{2}$ & 6.4 & 8.0 & 264 & 191 \\
\hline & $\mathrm{U}_{1} \mathrm{~T}_{1}$ & 2.9 & 4.1 & 235 & 178 \\
\hline & $\mathrm{U}_{0}^{1} \mathrm{~T}_{2}$ & 4.7 & 6.3 & 266 & 188 \\
\hline & $\mathrm{U}_{1}^{0} \mathrm{~T}_{2}^{2}$ & 5.4 & 7.0 & 298 & 165 \\
\hline \multirow[t]{4}{*}{ Peat soil } & $\mathrm{U}_{0}^{1} \mathrm{~T}_{1}^{2}$ & 4.3 & 5.6 & 566 & 143 \\
\hline & $\mathrm{U}_{1}^{0} \mathrm{~T}_{1}^{1}$ & 4.1 & 5.5 & 576 & 166 \\
\hline & $\mathrm{U}_{0}^{1} \mathrm{~T}_{2}$ & 8.5 & 10.1 & 371 & 188 \\
\hline & $\mathrm{U}_{1}^{0} \mathrm{~T}_{2}^{2}$ & 1.1 & 2.0 & 478 & 169 \\
\hline \multicolumn{6}{|c|}{ Second to fourth years $1994 / 95-1996 / 97$} \\
\hline \multirow[t]{4}{*}{ Clay } & $\mathrm{U}_{0} \mathrm{~T}_{1}$ & 11.8 & 13.1 & 340 & 296 \\
\hline & $\mathrm{U}_{1}^{0} \mathrm{~T}_{1}$ & 7.0 & 7.9 & 317 & 314 \\
\hline & $\mathrm{U}_{0}^{1} \mathrm{~T}_{2}^{1}$ & 16.4 & 17.8 & 366 & 327 \\
\hline & $\mathrm{U}_{1}^{0} \mathrm{~T}_{2}^{2}$ & 6.1 & 6.9 & 334 & 328 \\
\hline \multirow[t]{4}{*}{ Silt } & $\mathrm{U}_{0}^{1} \mathrm{~T}_{1}^{2}$ & 7.7 & 8.6 & 133 & 99 \\
\hline & $\mathrm{U}_{1} \mathrm{~T}_{1}$ & 3.6 & 3.9 & 71 & 48 \\
\hline & $\mathrm{U}_{0}^{1} \mathrm{~T}_{2}^{1}$ & 6.7 & 7.2 & 168 & 122 \\
\hline & $\mathrm{U}_{1}^{0} \mathrm{~T}_{2}^{2}$ & 6.4 & 7.0 & 124 & 83 \\
\hline \multirow[t]{4}{*}{ Sand } & $\mathrm{U}_{0}^{1} \mathrm{~T}_{1}^{2}$ & 32.3 & 35.5 & 561 & 274 \\
\hline & $\mathrm{U}_{1}^{0} \mathrm{~T}_{1}$ & 8.5 & 10.3 & 349 & 239 \\
\hline & $\mathrm{U}_{0}^{1} \mathrm{~T}_{2}^{1}$ & 25.0 & 27.9 & 452 & 225 \\
\hline & $\mathrm{U}_{1}^{0} \mathrm{~T}_{2}^{2}$ & 8.3 & 10.3 & 373 & 237 \\
\hline \multirow[t]{4}{*}{ Peat soil } & $\mathrm{U}_{0}^{1} \mathrm{~T}_{1}^{2}$ & 36.3 & 41.1 & 1195 & 272 \\
\hline & $\mathrm{U}_{1} \mathrm{~T}_{1}$ & 27.6 & 31.2 & 1436 & 298 \\
\hline & $\mathrm{U}_{0}^{1} \mathrm{~T}_{2}^{1}$ & 31.9 & 35.6 & 1517 & 314 \\
\hline & $\mathrm{U}_{1}^{0} \mathrm{~T}_{2}^{2}$ & 21.9 & 24.9 & 1476 & 329 \\
\hline \multicolumn{6}{|c|}{ After-effect year 1997/98 } \\
\hline \multirow[t]{4}{*}{ Clay } & $\mathrm{U}_{0} \mathrm{~T}_{1}$ & 19.3 & 20.6 & 494 & 385 \\
\hline & $\mathrm{U}_{1}^{0} \mathrm{~T}_{1}$ & 21.3 & 23.1 & 496 & 376 \\
\hline & $\mathrm{U}_{0}^{1} \mathrm{~T}_{2}^{1}$ & 20.0 & 22.2 & 462 & 411 \\
\hline & $\mathrm{U}_{1}^{0} \mathrm{~T}_{2}^{2}$ & 20.4 & 22.3 & 513 & 442 \\
\hline \multirow[t]{4}{*}{ Silt } & $\mathrm{U}_{0}^{1} \mathrm{~T}_{1}^{2}$ & 10.5 & 11.3 & 324 & 189 \\
\hline & $\mathrm{U}_{1}^{0} \mathrm{~T}_{1}^{1}$ & 6.3 & 6.8 & 247 & 151 \\
\hline & $\mathrm{U}_{0}^{1} \mathrm{~T}_{2}^{1}$ & 14.2 & 15.6 & 388 & 223 \\
\hline & $\mathrm{U}_{1}^{0} \mathrm{~T}_{2}^{2}$ & 5.6 & 6.4 & 344 & 229 \\
\hline \multirow[t]{4}{*}{ Sand } & $\mathrm{U}_{0}^{1} \mathrm{~T}_{1}^{2}$ & 39.0 & 44.5 & 513 & 295 \\
\hline & $\mathrm{U}_{1}^{0} \mathrm{~T}_{1}$ & 16.6 & 19.0 & 443 & 280 \\
\hline & $\mathrm{U}_{0}^{1} \mathrm{~T}_{2}$ & 35.3 & 39.2 & 648 & 334 \\
\hline & $\mathrm{U}_{1}^{0} \mathrm{~T}_{2}^{2}$ & 23.8 & 27.1 & 541 & 336 \\
\hline \multirow[t]{4}{*}{ Peat soil } & $\mathrm{U}_{0}^{1} \mathrm{~T}_{1}^{2}$ & 131.0 & 144.3 & 2576 & 444 \\
\hline & $\mathrm{U}_{1}^{0} \mathrm{~T}_{1}^{1}$ & 96.0 & 104.9 & 2544 & 463 \\
\hline & $\mathrm{U}_{0}^{1} \mathrm{~T}_{2}^{1}$ & 117.8 & 129.8 & 2528 & 492 \\
\hline & $\mathrm{U}_{1}^{0} \mathrm{~T}_{2}^{2}$ & 102.5 & 113.7 & 2612 & 578 \\
\hline
\end{tabular}

* Estimated means (square root of $\mathrm{NO}_{3}-\mathrm{N}$ and Tot-N leaching, logarithm of TS loss), which are transformed back to the original scale. 


\section{AGRICULTURAL AND FOOD SCIENCE IN FINLAND}

Vol. 9 (2000): 201-215.
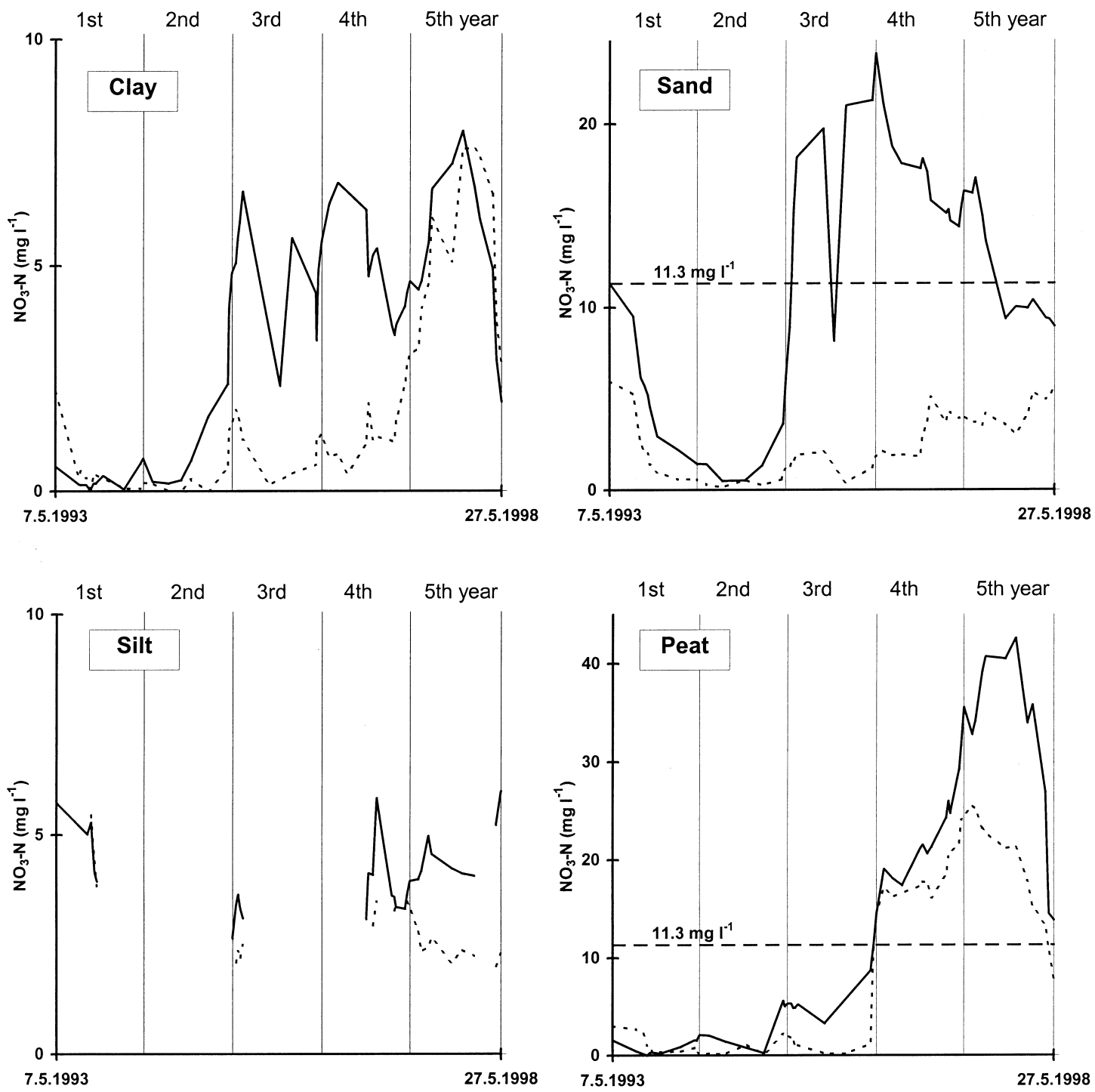

- No undersowing Autumn tillage

\section{Undersowing}

Autumn tillage

Fig. 1. Concentration of nitrate nitrogen $\left(\mathrm{NO}_{3}-\mathrm{N}, \mathrm{mg} \mathrm{l}^{-1}\right)$ in drainage water from eight representative lysimeters with different soils and treatments during five experimental years (fifth year with hay). $\mathrm{NO}_{3}-\mathrm{N}$ concentration limit for acceptable drinking water (WHO 1993) is denoted by dashed line. Note the different scales on the y-axes.

In clay and sand soil, undersowing of ryegrass efficiently reduced the $\mathrm{NO}_{3}-\mathrm{N}$ concentration in the third and fourth years (Fig. 1). In sand soil the after-effect of the previous experiment was clear at the beginning of the first experimental year when the $\mathrm{NO}_{3}-\mathrm{N}$ concentration was 
Lemola, R. et al. Undersowing Italian ryegrass diminishes $N$ leaching from spring barley

rather high. After that, concentration decreased to under $3 \mathrm{mg} \mathrm{l}^{-1}$ in all treatments, reflecting the minor losses of $\mathrm{N}$ from the lysimeters covered by ley in 1992. The effect of undersowing on $\mathrm{NO}_{3}-\mathrm{N}$ concentration was less in silt and peat soil, but the concentration was lowered in most cases (Fig. 1).

The effect of treatment on $\mathrm{NO}_{3}-\mathrm{N}$ leaching varied with soil type and experimental period $\left(\mathrm{F}_{18,22.9}=5.32, \mathrm{P}<0.001\right.$ for treatment*soil type* experimental period interaction), mainly because of differences in the concentration of $\mathrm{NO}_{3}-\mathrm{N}$ in the drainage water. $\mathrm{NO}_{3}-\mathrm{N}$ leaching losses were significantly reduced by undersowing, with the largest reductions in sand soil (Fig. 2). In the primary experimental years the reduction was 7.6, 2.2, 20 and $9.4 \mathrm{~kg} \mathrm{ha}^{-1} \mathrm{y}^{-1}$ in clay, silt, sand and peat soils, respectively. Nitrate was the main form of $\mathrm{N}$ lost; on average $86 \%$ of Tot-N in leachate was $\mathrm{NO}_{3}-\mathrm{N}$, the rest being mainly organic $\mathrm{N}$. Loss of $\mathrm{NH}_{4}-\mathrm{N}$ was very low in all treatments and soils, with an average of $0.08 \mathrm{~kg} \mathrm{ha}^{-1} \mathrm{y}^{-1}$ $\left(0.0050 .257 \mathrm{~kg} \mathrm{ha}^{-1} \mathrm{y}^{-1}\right)$.

Undersowing also decreased Tot-N leaching significantly $(\mathrm{P}<0.053)$, except in sand soil in the first experimental period $\left(\mathrm{t}_{32.4}=1.35\right.$, $\mathrm{P}=0.19)$ and clay soil in the after-effect year $\left(\mathrm{t}_{32.4}=-0.55, \mathrm{P}=0.59\right)$. In the primary experimental years, Tot-N leaching decreased by 52 , 31,68 and $27 \%$ in clay, silt, sand and peat, respectively (Table 3 ). The reduction in Tot- $\mathrm{N}$ leaching in the sand soil was $21 \mathrm{~kg} \mathrm{ha}^{-1} \mathrm{y}^{-1}$. Leaching was extremely high in peat soil in the last experimental year (average $123 \mathrm{~kg} \mathrm{ha}^{-1}$ ), partly due to low crop uptake of $\mathrm{N}$ caused by failure of the hay to establish.

Spring tillage reduced the leaching of $\mathrm{NO}_{3}$ $\mathrm{N}$ and Tot-N only in the peat soil and only during the primary experimental years $\left(\mathrm{t}_{32.1}=1.94\right.$, $\mathrm{P}=0.06$ and $\mathrm{t}_{32.4}=2.08, \mathrm{P}=0.05$, respectively). On peat soil, $\mathrm{NO}_{3}-\mathrm{N}$ concentration of drainage water was reduced by $22 \%$, on average, and Tot-N leaching was reduced by $5.9 \mathrm{~kg} \mathrm{ha}^{-1} \mathrm{y}^{-1}(16 \%)$ (Table 3). Except in the first year, spring tillage increased the loss of TS by 44-81 kg ha-1 $\mathrm{y}^{-1}$ in silt soil, and in the after-effect year it increased it by $117 \mathrm{~kg} \mathrm{ha}^{-1} \mathrm{y}^{-1}$ in sand soil.
Loss of TS in the drainage water was on average $321,127,392$ and $1303 \mathrm{~kg} \mathrm{ha}^{-1} \mathrm{y}^{-1}$ in clay, silt, sand and peat soils, respectively. The higher TS loss from peat soil was clearly due to dissolved organic matter, which also coloured the water brown. Undersowing decreased the TS loss in silt $\left(\mathrm{t}_{34.8}=4.42, \mathrm{P}<0.001\right)$ and sand $\left(\mathrm{t}_{34.8}=3.17\right.$, $\mathrm{P}<0.005)$ soils in the primary experimental years. Differences in the loss of TS were mainly due to the different amount of drainage - the greater water flow in the last two years leading to larger losses (Table 3).

\section{Yield and $\mathrm{N}$ uptake of barley and Italian ryegrass}

Average grain yield without undersown ryegrass was $4670,5620,4900$ and $5880 \mathrm{~kg} \mathrm{ha}^{-1} \mathrm{y}^{-1}$ dry matter (DM) in clay, silt, sand and peat soil, respectively. Although the grain yields with undersowing appeared slightly lower in clay and silt soil (1 and 6\%, respectively) and higher in sand soil (2\%), the differences were not significant. On peat soil, undersowing reduced the grain yield in the first year (by $1034 \mathrm{~kg} \mathrm{ha}^{-1}, \mathrm{t}_{9.9}=3.69$, $\mathrm{P}<0.005)$. The average $\mathrm{N}$ content of the barley grains without undersowing was 16, 14, 16 and $18 \mathrm{mg} \mathrm{g}^{-1} \mathrm{DM}$ in clay, silt, sand and peat soil, respectively. With undersowing the corresponding average $\mathrm{N}$ contents were 5, 2, 6 and $8 \%$ lower. The decrease was significant $(\mathrm{P}<0.05)$ in clay and peat soil in three years and in sand soil in one year. Spring tillage reduced grain yield significantly $\left(\mathrm{t}_{9.05}=4.88, \mathrm{P}<0.001\right)$ only in clay soil, by $560 \mathrm{~kg} \mathrm{ha}^{-1} \mathrm{y}^{-1}$. Tillage time did not affect $\mathrm{N}$ content of the yield.

In mineral soils, undersowing reduced the total $\mathrm{N}$ uptake of barley (grain + straw) on average by $5-8 \%\left(5-8 \mathrm{~kg} \mathrm{ha}^{-1} \mathrm{y}^{-1}\right)$ (Table 4$)$. $\mathrm{N}$ uptake by the ryegrass shoot was $3.7-41.7 \mathrm{~kg} \mathrm{ha}^{-1} \mathrm{y}^{-1}$, with the lowest values on clay and the highest on peat soil. On clay and silt soil with undersowing, $\mathrm{N}$ uptake of ryegrass was about twice as large as the reduction of the $\mathrm{N}$ uptake of barley (Table 4). On sand soil the $\mathrm{N}$ uptake of rye- 


\section{AGRICULTURAL AND FOOD SCIENCE IN FINLAND}

Vol. 9 (2000): 201-215.
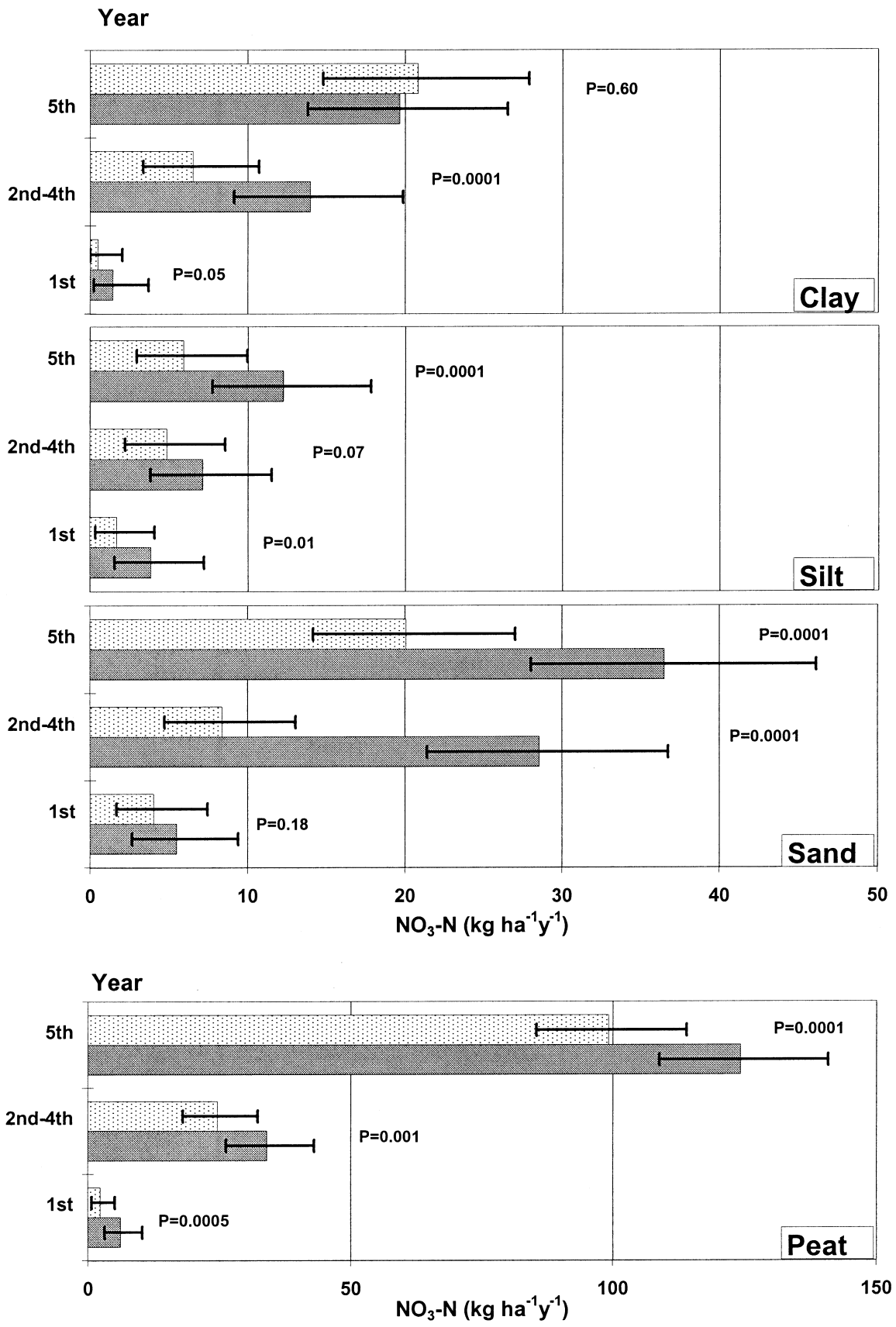

$\square$ No undersowing

口Undersowing

Fig. 2. Leaching of nitrate nitrogen $\left(\mathrm{NO}_{3}-\mathrm{N}, \mathrm{kg} \mathrm{ha}^{-1} \mathrm{y}^{-1}\right)$ during the first year, second to fourth years (primary experimental years) and fifth year (after-effect year with hay) from lysimeters with pure barley (no undersowing) and undersowing Italian ryegrass. $\mathrm{NO}_{3}-\mathrm{N}$ leaching and $95 \% \mathrm{CI}$ (segment of lines) are estimated means of square root, transformed back to the original scale. The $\mathrm{P}$ values are for the difference between undersowing and no undersowing. Note the different scales on the $\mathrm{x}$-axes. 
Lemola, $R$. et al. Undersowing Italian ryegrass diminishes $N$ leaching from spring barley

Table 4. $\mathrm{N}$ uptake of barley grain, barley straw and Italian ryegrass, and total uptake of $\mathrm{N}$ (grain + straw + ryegrass), Tot-N leaching and the difference $\left(\mathrm{U}_{0}-\mathrm{U}_{1}\right)$ in $\mathrm{N}$ uptake and leaching from treatments without undersowing $\left(\mathrm{U}_{0}\right)$ and with undersowing $\left(\mathrm{U}_{1}\right)$ of Italian ryegrass, average for four years (1993/941996/97).

\begin{tabular}{|c|c|c|c|c|c|c|}
\hline \multirow[t]{2}{*}{ Soil type } & \multirow[t]{2}{*}{ Treatment } & \multicolumn{4}{|c|}{$\begin{array}{l}\mathrm{N} \text { uptake } \\
\mathrm{kg} \mathrm{ha}^{-1} \mathrm{y}^{-1}\end{array}$} & \multirow[t]{2}{*}{$\begin{array}{c}\text { Tot-N leaching } \\
\mathrm{kg} \mathrm{ha}^{-1} \mathrm{y}^{-1}\end{array}$} \\
\hline & & Grain & Straw & Ryegrass & Total & \\
\hline \multirow[t]{3}{*}{ Clay } & $\mathrm{U}_{0}$ & 75.7 & 20.6 & \multirow{3}{*}{10.3} & 96.3 & 12.1 \\
\hline & $\mathrm{U}_{1}$ & 71.2 & 19.4 & & 100.9 & 5.7 \\
\hline & $\mathrm{U}_{0}^{1}-\mathrm{U}_{1}$ & 4.5 & 1.2 & & -4.6 & 6.4 \\
\hline \multirow[t]{3}{*}{ Silt } & $\mathrm{U}_{0}$ & 78.3 & 20.3 & \multirow{3}{*}{15.6} & 98.5 & 7.0 \\
\hline & $\mathrm{U}_{1}$ & 72.4 & 18.0 & & 106.1 & 4.5 \\
\hline & $\mathrm{U}_{0}-\mathrm{U}_{1}$ & 5.9 & 2.3 & & -7.6 & 2.5 \\
\hline \multirow[t]{3}{*}{ Sand } & $\mathrm{U}_{0}$ & 77.2 & 20.3 & \multirow{3}{*}{18.6} & 97.5 & 25.6 \\
\hline & $\mathrm{U}_{1}$ & 73.9 & 18.6 & & 111.1 & 9.1 \\
\hline & $\mathrm{U}_{0}-\mathrm{U}_{1}$ & 3.3 & 1.7 & & -13.6 & 16.5 \\
\hline \multirow[t]{3}{*}{ Peat } & $\mathrm{U}_{0}$ & 104.6 & 29.7 & \multirow{3}{*}{24.7} & 134.2 & 30.8 \\
\hline & $\mathrm{U}_{1}$ & 94.8 & 26.0 & & 145.6 & 22.0 \\
\hline & $\mathrm{U}_{0}-\mathrm{U}_{1}$ & 9.8 & 3.7 & & -11.4 & 8.8 \\
\hline
\end{tabular}

grass was four times the reduction. The reduction in $\mathrm{N}$ leaching from clay and sand when barley was undersown with ryegrass was nearly the same as the increased total uptake of $\mathrm{N}$ (barley + ryegrass). Compared with mineral soils, $\mathrm{N}$ uptake of barley grain and straw in peat soil was $31-36 \%$ and $39-46 \%$ higher, respectively. Undersowing reduced the $\mathrm{N}$ uptake of barley in peat soil by $10 \%\left(14 \mathrm{~kg} \mathrm{ha}^{-1} \mathrm{y}^{-1}\right)$, but $\mathrm{N}$ uptake by ryegrass was much higher than the reduction $(25$ $\left.\mathrm{kg} \mathrm{ha}^{-1} \mathrm{y}^{-1}\right)$. In contrast to clay and sand soils, the reduction in Tot-N leaching from peat soil due to undersowing was less than the increase in total $\mathrm{N}$ uptake.

\section{Discussion}

\section{Undersowing}

The growing period of the ryegrass between harvest of barley and soil freezing was only about 2-2.5 months. Still, undersowing of ryegrass re- duced the concentration of $\mathrm{NO}_{3}-\mathrm{N}$ in drainage water in all soils, with the largest effects on sand soil. The much lower Tot-N leaching from sand soil due to undersowing of Italian ryegrass shows that undersowing a catch crop has great potential for diminishing $\mathrm{N}$ leaching in southern Finland. The finding is in accordance with the results of Scandinavian studies where ryegrass was planted as catch crop on sandy and loamy soils: large reductions were found in $\mathrm{NO}_{3}-\mathrm{N}$ concentrations of soil water (Hansen and Djurhuus 1997, Stenberg et al. 1999) and reductions of 18$83 \%$ were recorded in $\mathrm{N}$ leaching (Table 5) (Lewan 1994, Sjödal Svensson et al. 1994, Uhlen et al. 1996, Hansen and Djurhuus 1997, Aronsson and Torstensson 1998). The average $\mathrm{N}$ uptake of ryegrass shoots measured in our experiment agrees with Danish experiments where the $\mathrm{N}$ content in unfertilized undersown ryegrass shoots was $16 \mathrm{~kg} \mathrm{ha}^{-1}$ (Andersen and Olsen 1993) and $23 \mathrm{~kg} \mathrm{ha}^{-1}$ (Jensen 1991) and the $\mathrm{N}$ content of roots $5.5 \mathrm{~kg} \mathrm{ha}^{-1}$ before ploughing in early December (Jensen 1991).

If $\mathrm{N}$ leaching is to be reduced, catch crops must (1) increase the amount of $\mathrm{N}$ stored in soil 
Vol. 9 (2000): 201-215.

Table 5. Change in Tot-N leaching (\%) due to undersowing of ryegrass as a catch crop compared with cultivation of spring cereals without undersowing. Catch crop: $\mathrm{I}=$ Italian ryegrass, $\mathrm{P}=$ perennial ryegrass. Method of study: $\mathrm{L}=1 \mathrm{ysimeters,} \mathrm{C}=$ ceramic cups, $\mathrm{F}$ = field experiment.

\begin{tabular}{|c|c|c|c|c|c|c|c|}
\hline \multirow[t]{2}{*}{$\begin{array}{l}\text { Catch } \\
\text { crop }\end{array}$} & \multirow{2}{*}{$\begin{array}{l}\text { Duration } \\
\text { of study, } \\
\text { years }\end{array}$} & \multirow{2}{*}{ Method } & \multirow[t]{2}{*}{ Soil type } & \multicolumn{2}{|c|}{$\begin{array}{l}\text { Change in Tot-N } \\
\text { leaching, } \%\end{array}$} & \multirow[t]{2}{*}{ Country } & \multirow[t]{2}{*}{ Reference } \\
\hline & & & & Autumn tillage & Spring tillage & & \\
\hline I & 2 & $\mathrm{~F}$ & sandy loam & & -81 & Sweden & Sjödahl Svensson et al. 1994 \\
\hline I & 4 & $\mathrm{~F}$ & sandy loam & & $-83 *$ & Sweden & Lewan 1994 \\
\hline $\mathrm{P}$ & 3 & $\mathrm{C}$ & sandy loam & & no effect $* *$ & Sweden & Stenberg et al. 1999 \\
\hline $\mathrm{P}$ & 3 & $\mathrm{~F}$ & sandy soil & & $-40-(-50)$ & Sweden & Aronsson and Torstensson 1998 \\
\hline $\mathrm{P}$ & 2 & $\mathrm{~L}$ & loam & -71 & & Norway & Uhlen et al. 1996 \\
\hline $\mathrm{P}$ & 2 & $\mathrm{~L}$ & loamy sand & -71 & & Norway & Uhlen et al. 1996 \\
\hline $\mathrm{P}$ & 5 & $\mathrm{C}$ & coarse sand & -37 & -58 & Denmark & Hansen and Djurhuus 1997 \\
\hline $\mathrm{P}$ & 4 & $\mathrm{C}$ & sandy loam & -18 & -49 & Denmark & Hansen and Djurhuus 1997 \\
\hline $\mathrm{I} * * *$ & 2 & $\mathrm{~L}$ & calcareous & & -67 & France & Martinez and Guiraud 1990 \\
\hline I & 4 & $\mathrm{~L}$ & clay & -41 & -61 & Finland & this study \\
\hline I & 4 & $\mathrm{~L}$ & silt & -58 & -7 & Finland & this study \\
\hline I & 4 & $\mathrm{~L}$ & sand & -69 & -58 & Finland & this study \\
\hline I & 4 & $\mathrm{~L}$ & peat & -23 & -34 & Finland & this study \\
\hline
\end{tabular}

* control treatment was stubble cultivated in autumn and ploughed in spring

** poor establishment and growth of catch crop during two out of three years

*** sowing after harvest of the main crop (intercropping)

as organic $\mathrm{N}$, (2) increase the amount of harvested $\mathrm{N}$ or (3) reduce the need for fertilizer $\mathrm{N}$ input (Thorup-Kristensen 1994). The first alternative is the most likely one for undersown ryegrass. However, while taking up and adding $\mathrm{N}$ to the organic $\mathrm{N}$ pool of the soil, the catch crop may also gradually increase the $\mathrm{N}$ mineralization potential of the soil. In Sweden, Lewan (1994) observed that the amount of $\mathrm{NO}_{3}-\mathrm{N}$ in the soil was reduced in the catch crop treatment, but increased during the fourth year when no catch crop was grown. Aronsson and Torstensson (1998) showed that there is an enhanced risk of $\mathrm{N}$ leaching after incorporation of catch crops, especially when the establishment of a new catch crop fails or crop uptake of $\mathrm{N}$ is small. In the present experiment, the after-effect period was too short to allow discovery of long-term effects of undersowing on $\mathrm{N}$ leaching. Moreover, the hay of the after-effect year was unfertilized, which probably served both to reduce $\mathrm{N}$ leaching and to moderate the differences between the treatments.

In several studies undersowing has slightly decreased the yield of the main crop (Kauppila 1985, Andersen and Olsen 1993, Beck-Friis et al. 1994, Nykänen-Kurki and Känkänen 1995, Breland 1996a, Lyngstad and Børresen 1996). Here the barley yield was not reduced. Italian ryegrass grew slowly until the main crop harvest, after which growth became vigorous. During the slow initial growth, competition for light, water and nutrients between the barley and catch crop was probably minimal. In Norway, Lyngstad and Børresen (1996) found that cover crop residues interfered with establishment of the grain crop for the next season. In our experiment, however, manual operations in the lysimeters probably allowed thorough and uniform incorporation of the ryegrass residues into the topsoil, even in the spring-tilled lysimeters. 
Lemola, R. et al. Undersowing Italian ryegrass diminishes $N$ leaching from spring barley

The somewhat lower $\mathrm{N}$ contents in barley grains and straw with undersowing indicated some competition between the ryegrass and barley, which may be explained by pre-emptive competition of ryegrass as described by Thorup-Kristensen (1993). By decreasing the mineral N content of the soil in autumn, the catch crop reduces the amount of mineral $\mathrm{N}$ available for the succeeding crop. Similar observations of lower N contents of the main crop have been made by Lewan (1994) and Lyngstad and Børresen (1996).

\section{Tillage time}

A number of Scandinavian studies have shown that delaying tillage operations until spring decreases the $\mathrm{N}$ leaching risk (Beck-Friis et al. 1994, Lyngstad and Børresen 1996, Djurhuus and Olsen 1997, Stenberg et al. 1999). We found no clear changes on mineral soils. However, the results might have been different if the autumn ploughing had been done a month earlier, because late autumn tillage decreases $\mathrm{N}$ leaching risk (Lindén and Wallgren 1993, Känkänen and Nykänen-Kurki 1997, Stenberg et al. 1999). In our case, tillage was possible in the middle of October because it was done manually with a spade, but such late tillage would not always be possible under field conditions.

The effect of postponing soil tillage to spring depends on soil temperatures in winter. The difference between autumn and spring tillage will clearly be less in areas of cold winters where soil temperature stays well below zero and prevents $\mathrm{N}$ mineralization. Sørensen and ThorupKristensen (1993) concluded that in areas where the soil is often frozen during winter, catch crops do not need to overwinter but can be incorporated in late autumn without risk of increased nitrate leaching. On the other hand, if temperatures are fluctuating near zero, mineralization may not be negligible. Van Schöll et al. (1997) found in a laboratory experiment that after a ten-week incubation at $1^{\circ} \mathrm{C}, 20 \%$ of the total organic $\mathrm{N}$ in catch crop material was mineralized. Thus the larger N leaching from autumn-tilled peat lysim- eters of the present study was probably due to the much higher mineralization potential of the peat than the mineral soil.

Spring tillage reduced the grain yield in clay soil, in accordance with observations in other studies (Mikkola 1989, Wallgren and Lindén 1994, Känkänen and Nykänen-Kurki 1997). Aronsson and Torstensson (1998) assumed that if plant material is incorporated in spring, increased $\mathrm{N}$ mineralization occurs too late to be fully available for the main crop. Känkänen and NykänenKurki (1997) recommended late autumn ploughing when considering both the $\mathrm{N}$ leaching risk and the grain yield of the following crop.

\section{Lysimeter vs. field conditions}

A comparison of the $\mathrm{N}$ leaching in clay lysimeters and the same clay soil in the field $2 \mathrm{~km}$ away ( 0.5 ha plots, $2 \%$ slope) suggested that $\mathrm{N}$ leaching was probably enhanced in the lysimeters. On the field site, $\mathrm{N}$ leaching from continuous barley cultivation without undersowing was 7-17 kg ha-1 $\mathrm{y}^{-1}$ (Turtola and Jaakkola 1985, Turtola and Lemola 2000), which was about $80 \%$ of the amount leached from the clay lysimeters. N leaching in the lysimeters may have been increased by both the shorter period of frost and the absence of surface runoff. Some surface runoff always exists in field conditions, varying with the hydraulic conductivity of the soil and the slope of the field, but it was prevented in the lysimeters, leading to above-normal drainage volumes. On the field plots mentioned above, the proportion of surface runoff ranged between 10 and $90 \%$ of total runoff (surface runoff + drainage), depending on the nature of the subsurface drainage system (Turtola and Paajanen 1995). In spring, particularly, the surface runoff during snowmelt may leach only small amounts of $\mathrm{N}$. Thus the leaching losses of $\mathrm{N}$ and the effects of treatments may be somewhat greater in lysimeters than in the field conditions. On silt soil, in contrast, high capillarity reduced drainage and $\mathrm{N}$ leaching from the silt lysimeters probably more than in the field, where water rising from 
Vol. 9 (2000): 201-215.

the groundwater may prevent the soil profile from drying completely during dry periods in summer.

The $220 \mathrm{~mm}$ of drainage required before the effect of the treatments was detected in the $\mathrm{NO}_{3}-\mathrm{N}$ concentration of the drainage indicates a rather non-preferential movement of water through soil profiles in the clay lysimeters. A more uniform movement of water in the clay lysimeters than in the clay soil profile in the field is also supported by (1) the much lower loss of TS in drainage from lysimeters than in drainage water from the same type of clay in the field (Turtola and Paajanen 1995) and (2) absence of large cracks or drain trenches in the lysimeters. It is also possible that high $\mathrm{NO}_{3}-\mathrm{N}$ concentrations in drainage in the first and second year may have been partly levelled off by the 'groundwater' storage of about $180 \mathrm{~mm}$ in the sand layer at the bottom of all lysimeters.

\section{Conclusions}

Considering the effects desired in real field conditions, i.e. low concentrations of $\mathrm{N}$ in drainage water from spring cereals, the results of our lysimeter experiment are encouraging. They suggest that undersowing Italian ryegrass would be particularly effective on sandy soils, without negative effects on spring grain yield. Postponing primary tillage to spring is not as effective as undersowing in reducing $\mathrm{N}$ leaching.

Acknowledgements. We express our thanks to Dr. Markku Yli-Halla and an anonymous referee for their useful comments, and to Dr. Kathleen Ahonen for linguistic revisions. The research was funded by the Ministry of Agriculture and Forestry.

\section{References}

Andersen, A. \& Olsen, C.C. 1993. Rye grass as a catch crop in spring barley. Acta Agriculturae Scandinavica Sect B, Soil and Plant Science 43: 218-230.

Aronsson, H. \& Torstensson, G. 1998. Measured and simulated availability and leaching of nitrogen associated with frequent use of catch crops. Soil Use and Management 14: 6-13.

Beck-Friis, B., Lindén, B., Marstorp, H. \& Henriksson, L. 1994. Kväve i mark och grödor i odlingssystem med fånggrödor. Undersökningar på en sandjord i södra Halland. Summary: Nitrogen in soil and crops in cropping systems with catch crop. Studies on a sand soil in south-west Sweden. Institutionen för markvetenskap. Avdelning för växtnäringslära. Rapport 193. Uppsala 1994. 36 p.

Breland, T.A. 1996a. Green manuring with clover and ryegrass catch crops undersown in small grains: crop development and yields. Acta Agriculturae Scandinavica Sect B, Soil and Plant Science 46: 30-40.

- 1996b. Green manuring with clover and ryegrass catch crops undersown in small grains: Effect on soil mineral nitrogen in field and laboratory experiments. Acta Agriculturae Scandinavica Sect B, Soil and Plant Science 46: 178-185.

Djurhuus, J. \& Olsen, P. 1997. Nitrate leaching after cut grass/clover leys as affected by time of ploughing. Soil Use and Management 13: 61-67.

Hansen, E.M. \& Djurhuus. J. 1997. Nitrate leaching as influenced by soil tillage and catch crop. Soil \& Tillage Research 41: 203-219.

Jaakkola, A. 1984. Leaching losses of nitrogen from a clay soil under grass and cereal crops in Finland. Plant and Soil 76: 59-66.

Jensen, E.S. 1991. Nitrogen accumulation and residual effects of nitrogen catch crops. Acta Agriculturae Scandinavica 41: 333-344.

Känkänen, H. 1995. The effect of undersown clover and grass on the nitrogen leaching risk during autumn and winter. Proceedings of NJF seminar no. 245. The use of catch or cover crops to reduce leaching and erosion, Knivsta, Sweden. NJF- Utredning/Rapport nr 99. p. 79-86.

- \& Nykänen-Kurki, P. 1997. Effect of incorporation time of different plant materials on soil mineral nitrogen content. The third workshop of EU concerted action (AIR3) 2108 Long term reduction of nitrate leaching by cover crops. 30 September - 3 October 1997, Southwell, UK. $16 \mathrm{p}$.

Karlsson-Strese, E.-M., Rydberg, I., Becker, H.C. \& Umaerus, M. 1998. Strategy for catch crop development. II Screening of species undersown in spring barley (Hordeum vulgare L.) with respect to catch crop growth and grain yield. Acta Agriculturae Scandinavica Sect B, Soil and Plant Science 48: 26-33.

Kauppila, R. 1985. Apilat aluskasveina viljanviljelyssä. Summary: Undersowing legumes for green manur- 


\section{AGRICULTURAL AND FOOD SCIENCE IN FINLAND}

\section{Lemola, $R$. et al. Undersowing Italian ryegrass diminishes $N$ leaching from spring barley}

ing of cereals. Biologisen typensidonnan ja ravinnetypen hyväksikäytön projekti. Julkaisu 20. p. 1-38.

Lewan, E. 1994. Effects of a catch crop on leaching of nitrogen from a sandy soil: Simulations and measurements. Plant and Soil 166: 137-152.

Lindén, B. \& Wallgren, B. 1993. Nitrogen mineralization after ploughing in early or late autumn. Swedish Journal of Argicultural Research 23: 77-89.

Littell, R.C., Milliken, G.A., Stroup, W.W. \& Wolfinger, R.D. 1996. SAS System for Mixed Models. Cary: NC:SAS Instiute Inc. 633 p.

Lyngstad, I. \& Børresen, T. 1996. Effects of undersown cover crops on yields and soil mineral nitrogen in cereal production in southeast Norway. Norwegian Journal of Agricultural Sciences 10: 55-70.

Martinez, J. \& Guiraud, G. 1990. A lysimeter study of the effects of a ryegrass catch crop, during a winter wheat/maize rotation, on nitrate leaching and on the following crop. Journal of Soil Science 41: 5-16.

Mikkola, H. 1989. Syyskyntöä korvaavien muokkausmenetelmien vaikutus kevätvehnän satoon 1975 1988. Summary: Effects of autumn ploughing and different reduced tillage methods on yield and quality of spring wheat 1975-1988. Vihti, State Research Institute of Engineering in Agriculture and Forestry. Vakolan tutkimusselostus 54: 2-32. ISSN 0782-0054.

Ministry of Environment 1998. Water Protection Targets to 2005. The Finnish Environment 226. Helsinki, Ministry of Environment. $82 \mathrm{p}$.

Nielsen, N.E. \& Jensen, H.E. 1985. Soil mineral nitrogen as affected by undersown catch crops. Assessment of nitrogen fertilizer requirement. Institute for Soil Fertility, Haren. p. 101-109.

Nykänen-Kurki, P. \& Känkänen, H. 1995. Role of undersowing in cereal crop rotation under extreme climatic conditions. Concerted action, EU AIR3 PL93 2108: Long term reduction of nitrate leaching by cover crops. 15-19 May 1995, Bennekom, the Netherlands. p. 86-98.

SAS Institute Inc. 1990. SAS® Procedure Guide. Version 6. 3rd ed. Cary, NC, USA. 705 p.

Schöll, L. van, Dam, A.M. van \& Leffelaar, P.A. 1997. Mineralisation of nitrogen from an incorporated catch crop at low temperatures: experiment and simulation. Plant and Soil 188: 211-219.

Sjödahl Svensson, K.S., Lewan, E. \& Clarholm, M. 1994. Effects of a ryegrass catch crop on microbial biomass and mineral nitrogen in an arable soil during winter. Swedish Journal of Agricultural Research 23: 31-38.
Sørensen, J.N. \& Thorup-Kristensen, K. 1993. Nitrogen effects of non-legume catch crops. Zeitschrift für Pflanzenernährung und Bodenkunde 156: 55-59.

Stenberg, M., Aronsson, H., Lindén, B., Rydberg, T. \& Gustafson, A. 1999. Soil mineral nitrogen and nitrate leaching losses in soil tillage systems combined with a catch crop. Soil \& Tillage Research 50: 115-125.

Thorup-Kristensen, K. 1993. The effect of nitrogen catch crops on the nitrogen nutrition of a succeeding crop. I. Effects through mineralization and pre-emptive competition. Acta Acriculturae Scandinavica Sect B, Soil and Plant Science 43: 74-81.

- 1994. The effect of nitrogen catch crop species on the nitrogen nutrition of succeeding crops. Fertilizer Research 37: 227-234.

Turtola, E. \& Jaakkola, A. 1985. Viljelykasvin ja lannoitustason vaikutus typen ja fosforin huuhtoutumiseen savimaasta. (Effect of crop and fertilizing on nitrogen and phosphorus leaching from clay soil.) Jokioinen, Maatalouden tutkimuskeskus. Tiedote 6/85. 43 p. ISSN 0359-7652.

- \& Paajanen, A. 1995. Influence of improved subsurface drainage on phosphorus losses and nitrogen leaching from a heavy clay soil. Agricultural Water Management 28: 295-310.

- \& Lemola, R. 2000. Vesistökuormitus kyntämättä viljelyssä. (Nutrient load to waters from reduced tillage.) Jokioinen, Maatalouden tutkimuskeskus. 22 + 14 p. ISBN 951-729-576-6.

Uhlen, G., Bakken, L. \& Haugen, L.E. 1996. Nutrient and water balances in lysimeter experiments. II. Nitrogen and mineral leaching and balances. Norwegian Journal of Agricultural Sciences 10: 339-354.

Verbeke, G. \& Molenberghs, G. (eds.). 1997. Lecture notes in statistics 126. Linear mixed models in practise: A SAS-oriented approach. New York, SpringerVerlag Inc. $306 \mathrm{p}$.

Wallgren, B. \& Lindén, B. 1994. Effects of catch crops and ploughing times on soil mineral nitrogen. Swedish Journal of Agricultural Research 24: 67-75.

WHO 1993. Guidelines for drinking-water quality, vol. 1. Recommendations. 2nd ed. Geneva, Switzerland, World Health Organization. $188 \mathrm{p}$.

Yandell, B.S. 1997. Practical data analysis for designed experiments. Chapman \& Hall. $437 p$.

Yearbook of Farm Statistics 1999. SVT. Agriculture and forestry 1999:12. Helsinki, Information Centre of the Ministry of Agriculture and Forestry. 262 p. 
Vol. 9 (2000): 201-215.

\title{
SELOSTUS
}

\section{Italian raiheinä aluskasvina vähentää typen huuhtoutumista ohranviljelyssä}

\author{
Riitta Lemola, Eila Turtola ja Christian Eriksson \\ Maatalouden tutkimuskeskus
}

Savi-, hiesu-, hieta- ja turvelysimetreissä tutkittiin aluskasviksi kylvetyn Italian raiheinän ja muokkausajan vaikutusta typen huuhtoutumiseen ja pääkasvina kasvaneen ohran satoon Jokioisissa vuosina 19931996. Kivennäismaille annettiin vuosittain lannoitetyppeä, -fosforia ja -kaliumia 90, 25 ja $50 \mathrm{~kg} \mathrm{ha}^{-1}$ ja turvemaalle 45,16 ja $37 \mathrm{~kg} \mathrm{ha}^{-1}$. Jälkivaikutusvuonna 1997 kaikkiin lysimetreihin kylvettiin timotei-nurminata -siemenseos ilman lannoitusta.

Aluskasvi vähensi typen huuhtoutumista jo ensimmäisenä koevuonna, jolloin huuhtoutuminen oli kuitenkin pientä johtuen koetta edeltäneestä lannoittamattomasta nurmesta. Varsinaisena koejaksona (2., 3. ja 4. vuosi) kokonaistypen huuhtoutuminen väheni savella $52 \%$, hiedalla $68 \%$, hiesulla $31 \%$ ja turvemaalla $27 \%$. Huuhtoutuneesta kokonaistypestä oli nitraattityppeä $86 \%$. Typen huuhtoutuminen väheni määrällisesti eniten hietamaalla $\left(21 \mathrm{~kg} \mathrm{ha}^{-1} \mathrm{y}^{-1}\right)$. Hietamaalla valumaveden nitraattityppipitoisuus ylitti juomavedelle asetetun raja-arvon $\left(11,3 \mathrm{mg} \mathrm{l}^{-1}\right)$ viljeltäessä ohraa ilman aluskasvia. Aluskasvi sen sijaan esti nitraattipitoisuuden nousun haitallisen korkeak- si. Aluskasvin viljely ei pienentänyt ohran jyväsatoa, mutta se alensi jyvien typpipitoisuutta. Pitkäaikaisvaikutusten selvittämiseen koejakso oli liian lyhyt.

Perusmuokkaus tehtiin lapiolla $20 \mathrm{~cm}$ syvyyteen joko syksyllä lokakuun puolivälissä tai keväällä juuri ennen kylvöä. Kevätmuokkaus ei vähentänyt typen huuhtoutumista, mikä todennäköisesti johtui syysmuokkauksen myöhäisyydestä. Tällöin syksyllä maahan muokattujen kasvinjäänteiden ja maan orgaanisen aineksen sisältämä typpi ei ehtinyt mineraloitua ennen maan jäätymistä ja aiheuttaa typen huuhtoutumista kevätvalunnan aikana. Muokkauksen siirtäminen kevääseen pienensi jyväsatoa savimaalla.

Tulosten perusteella Italian raiheinää voidaan suositella aluskasviksi erityisesti hietamaille vähentämään typen huuhtoutumista kevätviljoilta. Kun nurmi perustetaan suojaviljaan, typen huuhtoutuminen voi vähentyä perustamisvuonna lähes aluskasviviljelyä vastaavasti. Myöhäinen syysmuokkaus näyttää kevätmuokkauksen veroiselta keinolta vähentää typen huuhtoutumista. 